\title{
Expression of the potential therapeutic target CXXC5 in primary acute myeloid leukemia cells - high expression is associated with adverse prognosis as well as altered intracellular signaling and transcriptional regulation
}

\author{
Øystein Bruserud ${ }^{1,2}$, Håkon Reikvam ${ }^{1,2}$, Hanne Fredly ${ }^{1,2}$, Jørn Skavland², Karen- \\ Marie Hagen ${ }^{1}$, Tuyen Thy van Hoang ${ }^{1}$, Annette K. Brenner ${ }^{1}$, Amir Kadi ${ }^{4,5,6}$, Audrey \\ Astori $^{4,5,6}$, Bjørn Tore Gjertsen ${ }^{1,2}$ and Frederic Pendino ${ }^{3,4,5,6}$ \\ ${ }^{1}$ Section for Hematology, Department of Clinical Science, University of Bergen, Norway \\ 2 Department of Medicine, Haukeland University Hospital, Bergen, Norway \\ ${ }^{3}$ Department of Molecular Biology, University of Bergen, Bergen, Norway \\ ${ }^{4}$ Inserm, U1016, Institut Cochin, F-75014, Paris, France \\ ${ }^{5}$ CNRS, UMR8104, F-75014, Paris, France \\ ${ }^{6}$ Université Paris Descartes, Sorbonne Paris Cité, Paris, France \\ Correspondence to: Øystein Bruserud, email: oysteinbruserud@yahoo.no \\ Keywords: Acute myeloid leukemia, CXXC5, transcription, cytokines, all-trans retinoic acid \\ Received: April 20, $2014 \quad$ Accepted: December 21,2014 Published: December 26, 2014
}

This is an open-access article distributed under the terms of the Creative Commons Attribution License, which permits unrestricted use, distribution, and reproduction in any medium, provided the original author and source are credited.

\section{ABSTRACT}

The CXXC5 gene encodes a transcriptional activator with a zinc-finger domain, and high expression in human acute myeloid leukemia (AML) cells is associated with adverse prognosis. We now characterized the biological context of CXXC5 expression in primary human AML cells. The global gene expression profile of AML cells derived from 48 consecutive patients was analyzed; cells with high and low CXXC5 expression then showed major differences with regard to extracellular communication and intracellular signaling. We observed significant differences in the phosphorylation status of several intracellular signaling mediators (CREB, PDK1, SRC, STAT1, P38, STAT3, rpS6) that are important for PI3K-Akt-mTOR signaling and/or transcriptional regulation. High CXXC5 expression was also associated with high mRNA expression of several stem cell-associated transcriptional regulators, the strongest associations being with WT1, GATA2, RUNX1, LYL1, DNMT3, SPI1, and MYB. Finally, CXXC5 knockdown in human AML cell lines caused significantly increased expression of the potential tumor suppressor gene TSC22 and genes encoding the growth factor receptor KIT, the cytokine Angiopoietin 1 and the selenium-containing glycoprotein Selenoprotein P. Thus, high CXXC5 expression seems to affect several steps in human leukemogenesis, including intracellular events as well as extracellular communication.

\section{INTRODUCTION}

CXXC5 is a retinoid-responsive gene localized to the $5 \mathrm{q} 31.3$ chromosomal region [1] and encoding a retinoid-inducible nuclear factor (RINF) [2] that is a protein containing a CXXC-type zinc-finger domain and acting as a transcription regulator [3]. Expression studies as well as gene silencing experiments suggest that CXXC5 is important in normal myelopoiesis [2] and for differentiation of endothelial cells [3]. Furthermore, we recently described that CXXC5 is expressed in primary acute myeloid leukemia (AML) cells; this expression shows a wide variation between patients and high levels are associated with an adverse prognosis and resistance to chemotherapy-induced apoptosis [4]. Another study recently confirmed our observations and CXXC5 expression was then of independent prognostic significance in multivariate analyses after adjustment 
for age, white blood cell count, cytogenetic risk group, FLT3-ITD status, biallelic CEBPA mutations, as well as mutations of NPM1, DNMT3A and ASXL1 [5]. Based on these observations we suggest that $\mathrm{CXXC5}$ should be considered as a possible therapeutic target in human AML. However, more detailed preclinical evaluation of CXXC5 as a possible therapeutic target is needed. In the present study we characterized the biological context of high CXXC5 expression and effects of CXXC5 knockdown in human AML cells.

\section{MATERIAL AND METHODS}

\section{AML patients and preparation of primary AML cells}

The study was approved by the Regional Ethics Committee III, University of Bergen, Norway). Samples were collected after written informed consent, and we included consecutive and thereby unselected patients with high peripheral blood blast counts $\left(>7 \times 10^{9} / \mathrm{L}\right)$ (Table 1$)$. These selections of patients as well as the analysis of FLT3 and NPM1 mutations have been described previously [6, 7]. AML cells were isolated by density gradient separation alone (Lymphoprep, Axis-Shield, Oslo, Norway) and contained at least 95\% leukemic blasts. The cells were stored in liquid nitrogen until used in the experiments [6]. CXXC5 expression was determined by PCR analysis for a cohort of 67 consecutive patients and global gene expression profiles were analysed in a second cohort of 48 consecutive patients; there was an overlap of 24 patients between the cohorts (see later, Suppl. Fig. 1).

\section{AML cell lines}

Human leukemic cell lines were purchased from DSMZ (MV4-11; Braunschweig, Germany) and from the American Type Culture Collection (K562; Molsheim, France). UT7 5.3 cells were kindly provided by Isabelle Dusanter-Fourt (Cochin Institute, Paris, France). K562 and MV4-11 were cultured in RPMI 1640 medium supplemented with $10 \%$ fetal calf serum (FCS), 2 $\mathrm{mM}$ L-Glutamine, $50 \mathrm{U} / \mathrm{ml}$ penicillin $\mathrm{G}$ and $50 \mu \mathrm{g} / \mathrm{ml}$ streptomycin (Life Technologies, Saint-Aubin, France). UT7 5.3 cells were cultured in minimum essential medium (MEM) $\alpha$ medium containing $10 \%$ of FCS, 2 $\mathrm{mM}$ L-Glutamine, $50 \mathrm{U} / \mathrm{ml}$ penicillin $\mathrm{G}$ and $50 \mu \mathrm{g} / \mathrm{ml}$ streptomycin (Life Technologies, Saint-Aubin, France) and 2,5 ng/ $\mu$ l of GM-CSF (Myltenyi Biotech, France).

\section{RNA purification and quantitative RT-PCR analysis of CXXC5 messenger RNA expression}

The methods for purification of total RNA, complementary DNA synthesis and quantitative PCRs (qPCR) have been described in detail previously [4]. Relative messenger RNA (mRNA) expression was normalized to ribosomal protein P2 (RPLP2) gene expression in a two-colour duplex reaction.

\section{RNA preparation, labeling and microarray hybridization for primary human AML cells}

Microarray analyses were performed using Illumina iScan Reader based on fluorescent detection of biotinlabeled cRNA. Total RNA (300 ng) from each sample was reversely transcribed, amplified and Biotin-16-UTPlabelled using Illumina TotalPrep RNA Amplification Kit (Life Technologies, Foster City, CA, USA). Amount and quality of biotin-labeled cRNA was controlled by NanoDrop spectrophotometer and by Agilent 2100 Bioanalyser (Agilent Technologies, Santa Clara, CA, USA). Biotin-labeled cRNA (750 ng) was hybridized to HumanHT-12V4 Expression BeadChip according to the manufacturer's instructions. The HumanHT-12V4 BeadChip targets 47231 probe was based primarily on genes in the National Center for Biotechnology Information RefSeq database (Release 38; ftp://ftp.cbi. edu.cn/pub/database/refseq/release/release-notes/archive/ RefSeq-release38.txt).

\section{In vitro culture of primary human AML cells}

Drugs. Lenalidomide (Selleck Chemicals, Munich, Germany) was used at $0.5 \mu \mathrm{M}$. The mTOR inhibitor rapamycin was purchased from LC Laboratories (Woburn, MA, USA) and the pan-PI3K inhibitor GDC-0941 from Axon Mechen (BV, Groningen, the Netherlands); both were used at $1.0 \mu \mathrm{M}$. 17-dimethylaminoethylamino17-demethoxygeldanamycin (17-DMAG) (Infinity Pharmaceuticals, Cambridge, MA, USA) was used at $1.0 \mu \mathrm{M}$. Bortezomib was purchased from Jansen-Cilag (Beerse, Belgium) and used at $25 \mathrm{nM}$. Ingenol-3 angelate (PEP005) was supplied by Peplin Ltd (Brisbane, Australia) and used at $20 \mathrm{nM}$. Protein kinase inhibitors were all purchased from Biaffin GmbH (Kassel, Germany); PD98059 was used at $20 \mu \mathrm{M}$ whereas SB202190 and SP600125 were used at $1 \mu \mathrm{M}$. All drug solutions except GDC-0941 were prepared in dimethylsulphoxide (DMSO) or ethanol; pilot experiments demonstrated that DMSO or ethanol at the final concentrations used in the experiments did not affect AML cells.

Cell culture. Cells were cultured in StemSpan serum-free medium supplemented with $100 \mu \mathrm{g} / \mathrm{ml}$ of 
gentamicin (Stem Cell Technologies Inc, Vancouver, BC, Canada) [8]. AML cells ( 1 x $10^{6}$ cells $\left./ \mathrm{ml}\right)$ were cultured at $37^{\circ} \mathrm{C}$ in a humidified atmosphere of $5 \% \mathrm{CO}_{2}$. Cytokine levels in supernatants were analysed by Luminex methodology after 48 hours of culture (Bio-Plex human cytokine group, Bio-Rad, Oslo, Norway) [7-9]. AML cell viability/apoptosis was analysed by flow cytometry $[10$, $11]$.

\section{Intracellular protein phosphorylation}

Protein phosphorylation was analyzed by flow cytometry as described in detail previously [12-14].

\section{CXXC5 knockdown and global gene expression analyses of AML cell lines}

CXXC5 knockdown. K562 and UT7.3 cells were transduced with the pTRIP lentiviral vector that drives the constitutive expression of GFP (Green Fluorescent Protein) for cell sorting, and either a short-hairpin RNA [shRNA] targeting RINF sequence (shRNA-RINF) or a non-relevant sequence (non-target-shRNA control) as described in detail previously [1]. K562 and MV411 were also transduced with the previously described pLKO.1/shRNA-RINF and pLKO.1/shRNA-nontarget that drives the expression the puromycine resistant gene for the selection of the cells [1]. Lentiviral plasmids (pLKO.1/short hairpin RNA [shRNA]/RINF) targeting RINF expression were purchased from Sigma-Aldrich (MISSION shRNA Bacterial Glycerol Stock), and control vectors ( $\mathrm{pLKO} .1 / \mathrm{TRC}$ and $\mathrm{pLKO} .1 / \mathrm{shRNA} / \mathrm{scramble}$ controls) were kindly provided by David Root and David M. Sabatini (both from Massachusetts Institute of Technology, Cambridge, MA; Addgene plasmids 10879 and 1864). Briefly, production of lentiviral particles were performed by transient cotransfection (with Fugene HD) of HEK 293 T cells with the second generation packaging system (e.g., packaging plasmid psPAX2 and envelope plasmid pMD2.G) developed by D. Trono's laboratory (Ecole Polytechnique Fédérale de Lausanne, Lausanne, Switzerland; Addgene plasmids 12260 and 12259). Viral supernatants were harvested and filtered 2 days posttransfection and then applied to growing cells for spin infection (2400 rpm for 1 hour at room temperature), which was carried out in presence of $5 \mu \mathrm{g} / \mathrm{mL}$ proteamine sulfate. Two days after infection, AML cells were selected for at least 2 days with puromycine (Sigma-Aldrich) at 1 $\mu \mathrm{g} / \mathrm{mL}$.

Our methods for knockdown, verification of the knockdown at the protein and mRNA level, and analysis of the effects of knockdown on proliferation and apoptosis have been described in detail in our previous publication [4]. The knockdown alone did not affect proliferation or viability of the AML cell lines, and the efficiency of the knockdown was verified both at the mRNA and protein level for each cell line in every experiment.

Analysis of global gene expression profiles. After validation of RNA quality with Bioanalyzer 2100 (using Agilent RNA6000 nano chip kit), $400 \mathrm{ng}$ of total RNA was reverse transcribed following the Genechip WT plus Reagent kit (Affymetrix). Briefly, the resulting double strand cDNA was used for in vitro transcription with T7 RNA pol. After purification, $15 \mu \mathrm{g}$ of cRNA was used for reverse transcription with random primers. The cDNA obtained was then purified and fragmented. After control of fragmentation using Bioanalyzer 2100, cDNA was end labeled with biotin using Terminal Transferase (using the WT terminal labeling kit of Affymetrix). cDNA was then hybridized to GeneChip ${ }^{\circledR}$ Human Transcriptome Analysis 2.0 (Affymetrix) at $45^{\circ} \mathrm{C}$ for 17 hours. After overnight hybridization, chips were washed on the fluidic station FS450 following specific protocols (Affymetrix) and scanned using the GCS3000 7G. The image was then analyzed with Expression Console software (Affymetrix) to obtain raw data (cel files) and metrics for Quality Controls. Minimum information about a microarray experiment (MIAME)-compliant documentation of the microarray experiments have been deposited in Array Express at the European Bioinformatics Institute (http:// www.ebi.ac.uk/arrayexpress). The Affymetrix HTA2 dataset analysis was performed by GenoSplice technology (www.genosplice.com). Data were normalized using quantile normalization. Background corrections were made with antigenomic probes and probes were selected according to their $\% \mathrm{GC}$, cross-hybridization status and potential overlap with repeat region as previously described $[15,16]$. Only probes targeting exons and exonexon junctions annotated from FAST DB ${ }^{\circledR}$ transcripts (release fastdb_2014_1) were selected [17, 18]. Only genes expressed in at least one compared condition were analyzed. To be considered to be expressed, the DABG $\mathrm{P}$-value had to be $\leq 0.05$ for at least half of the gene probes. We performed an unpaired Student's t-test to compare gene intensities between shRINF and shCTRL cells. Genes were considered significantly regulated when foldchange was $\geq 1.5$, a fold-change noticed for CXXC5 genes for which we have validated the knock-down by q-RTPCR and western-blot analysis.

\section{Analyses of the data}

For statistical comparisons between different groups we used the Mann-Whitney U-test, for analyses of paired observations the Wilcoxon's signed rank test was used and for correlation analyses we used the Pearson's correlation test. Differences were regarded as significant when $\mathrm{p}<0.05$. Bioinformatical analyses of gene expression data were performed using the J-Express (MolMine AS, Bergen, Norway); whereas our analysis of protein functions was based on the Panther (http://www.pantherdb.org/) and 
Reactome (http://www.reactome.org/) databases.

\section{RESULTS}

\section{Global gene expression profiles differ between AML cells with high and low $\mathrm{CXXC5}$ expression}

CXXC5 expression was analyzed by PCR for a total of 67 patients who were included in the study (Table 1). When comparing the 34 patients with low and the 33 patients with high $\mathrm{CXXC5}$ expression we confirmed that monocytic differentiation of the leukemic cells (FAB-M4/M5) was associated with low expression compared with neutrophilic differentiation (FAB-M2) [4], whereas $\mathrm{CXXC5}^{\mathrm{HIGH}}$ and $\mathrm{CXXC5}^{\text {LOW }}$ patients did not differ significantly for any other parameter, including the percentage of patients with at least one risk factor for chemoresistance (i.e. secondary leukemia, relapsed disease, adverse cytogenetic abnormalities or Flt3ITD). Similar results were observed when comparing $\mathrm{CXXC}^{\mathrm{HIGH}}$ and $\mathrm{CXXC5} 5^{\mathrm{LOW}}$ patients in the microarray cohort $(\mathrm{n}=48)$ (data not shown). Both cohorts included consecutive and thereby unselected patients and 24 patients were included in both cohorts; a strong correlation was then observed for these patients when comparing CXXC5 levels determined by PCR and microarray analyses (Suppl. Fig. 1; r $=0.7665$ p $<0.0001$, Pearson's correlation test).

We did a Gene Set Enrichment Analysis (GSEA) where we compared the 15 patients with the highest and the 15 patients with the lowest CXXC5 expression, and we then identified 38 GO-terms with a false discovery rate $(\mathrm{RDR})<1.0$. All GO-terms were enriched in the $\mathrm{CXXC5}^{\mathrm{LOw}}$ group, and we identified 571 genes that belonged to the leading edge for at least one of these 38 terms. When these 571 genes were used in a hierarchical clustering analysis we identified two main subsets corresponding to the original $\mathrm{CXXC}^{\mathrm{LOW}}$ and $\mathrm{CXXC}^{\mathrm{HIGH}}$ patient subsets (Suppl. Fig. 2).

The 38 GO-annotations identified above (Suppl. Fig.

2) could be classified into three main groups; extracellular communication ( 9 annotations), intracellular signaling and trafficking (13 annotations), and a third heterogeneous group including regulation of cell shape, inflammatory and metabolic responses (16 annotations) (Supplementary Table 2). Firstly, $\mathrm{CXXC}^{\mathrm{HIGH}}$ and $\mathrm{CXXC}^{\mathrm{LOW}}$ patients differed with regard to extracellular communication including cytokine production (IL6, TNF $\alpha$ ), integrinmediated signaling and expression of immunoglobulin superfamily members (i.e. a family including adhesion molecules and cytokine receptors). Secondly, the intracellular signaling and trafficking group included the wide terms Response to zinc and Lysosome, but in addition terms reflecting differences in signaling mediated by Toll-like receptor-linked pathways, MAP kinases and ARF/GTP-ase. The differences in intracellular trafficking

\section{Panther Protein Class}

\section{Genes identified in the $38 \mathrm{GO}$-terms enriched in CXXC5 ${ }^{\text {low }}$ $(n=571)$}

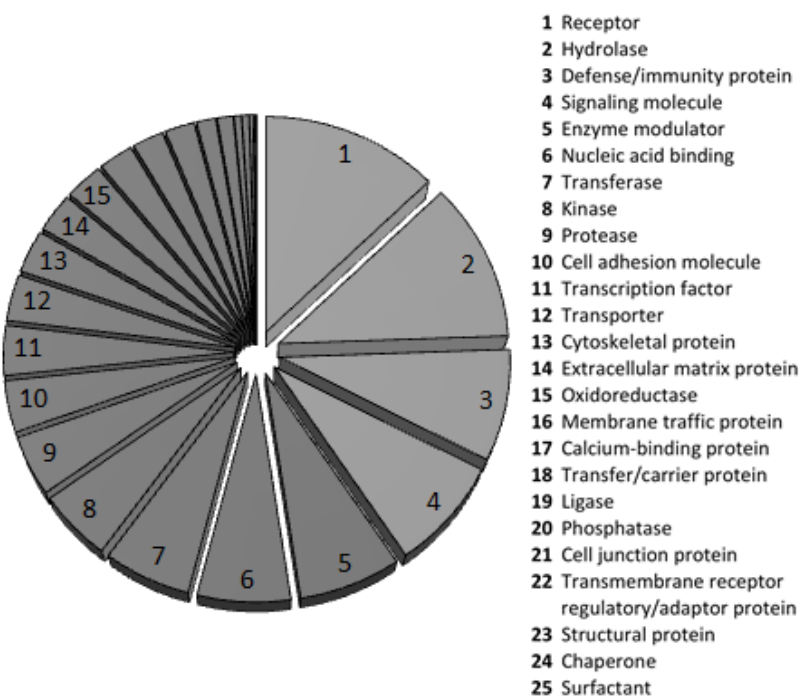

Genes expressed in correlation with CXXC5 $(n=200)$

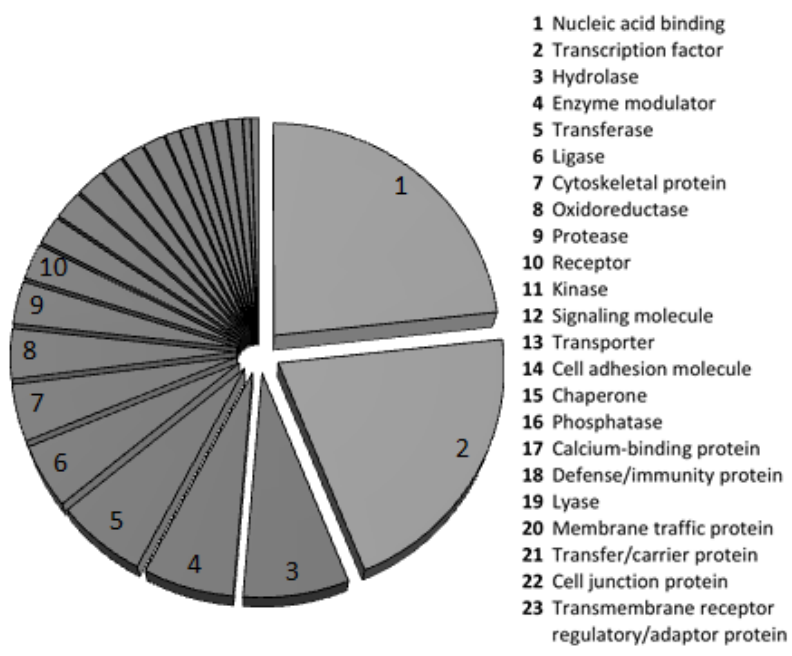

Figure 1: Protein class analysis of the genes showing differential expression for CXXC5 $5^{\mathrm{HIGH}}$ and $\mathrm{CXXC5}^{\mathrm{LOW}}$ patients in GSEA analysis (left, 571 genes identified) and similarity profiling analysis (right, the 200 genes with the strongest correlation being analyzed). The genes were analyzed according to their functional protein class based on the Panther (http://www. pantherdb.org/) database. The various protein classes were ranked according to the number genes included in each of the classes. 
Table 1: Clinical and biological characteristics of the AML patients included in the study.

\begin{tabular}{|c|c|c|c|}
\hline Parameter & All 67 patients & $\begin{array}{l}\text { Low CXXC5 expression } \\
34 \text { patients }\end{array}$ & $\begin{array}{l}\text { High CXXC5 } \\
\text { expression } \\
33 \text { patients }\end{array}$ \\
\hline Age (years; median/range) & 64 years $(27-88$ years $)$ & 61 years $(29-88$ years $)$ & \begin{tabular}{|l}
70 years $(27-$ \\
83 years $)$ \\
\end{tabular} \\
\hline Gender distribution (female/male) & $30 / 37$ & $16 / 18$ & $13 / 20$ \\
\hline $\begin{array}{l}\text { Percentage of patients with: } \\
\text { AML secondary to chemotherapy } \\
\text { AML secondary to myeloid malignancies (MDS, } \\
\text { chronic myeloid neoplasia) } \\
\text { de novo AML }\end{array}$ & $\begin{array}{l}8 \% \\
24 \% \\
68 \% \\
\end{array}$ & $\begin{array}{l}12 \% \\
18 \% \\
70 \% \\
\end{array}$ & $\begin{array}{l}3 \% \\
30 \% \\
67 \% \\
\end{array}$ \\
\hline Relapse at the time of examination & $21 \%$ & $15 \%$ & $27 \%$ \\
\hline $\begin{array}{l}\text { FAB classification } \\
\text { M0/M1 } \\
\text { M2 } \\
\text { M4/M5 }\end{array}$ & $\begin{array}{l}36 \% \\
26 \% \\
38 \% \\
\end{array}$ & $\begin{array}{l}24 \% \\
27 \% \\
49 \% \\
\end{array}$ & $\begin{array}{l}48 \% \\
26 \% \\
26 \% \\
\end{array}$ \\
\hline Expression of CD34 (>20\% positive AML cells) & $54 \%$ & $54 \%$ & $54 \%$ \\
\hline $\begin{array}{l}\text { Cytogenetic abnormalities } \\
\text { Normal } \\
\text { Good } \\
\text { Intermediate } \\
\text { Adverse } \\
\end{array}$ & \begin{tabular}{|l|}
$59 \%$ \\
$8 \%$ \\
$9 \%$ \\
$27 \%$ \\
\end{tabular} & $\begin{array}{l}54 \% \\
17 \% \\
4 \% \\
25 \% \\
\end{array}$ & $\begin{array}{l}64 \% \\
0 \\
12 \% \\
30 \% \\
\end{array}$ \\
\hline Flt3 internal tandem duplication (ITD) & $32 \%$ & $29 \%$ & $37 \%$ \\
\hline NPM-1 mutations & $45 \%$ & $45 \%$ & $45 \%$ \\
\hline
\end{tabular}

Favourable cytogenetic abnormalities include $\operatorname{inv}(16) / \mathrm{t}(16 ; 16)$ and $\mathrm{t}(8 ; 21)$; adverse include multiple ( $\geq 3$ abnormalities), $\mathrm{t}(3: 3)$, del7 and del5.
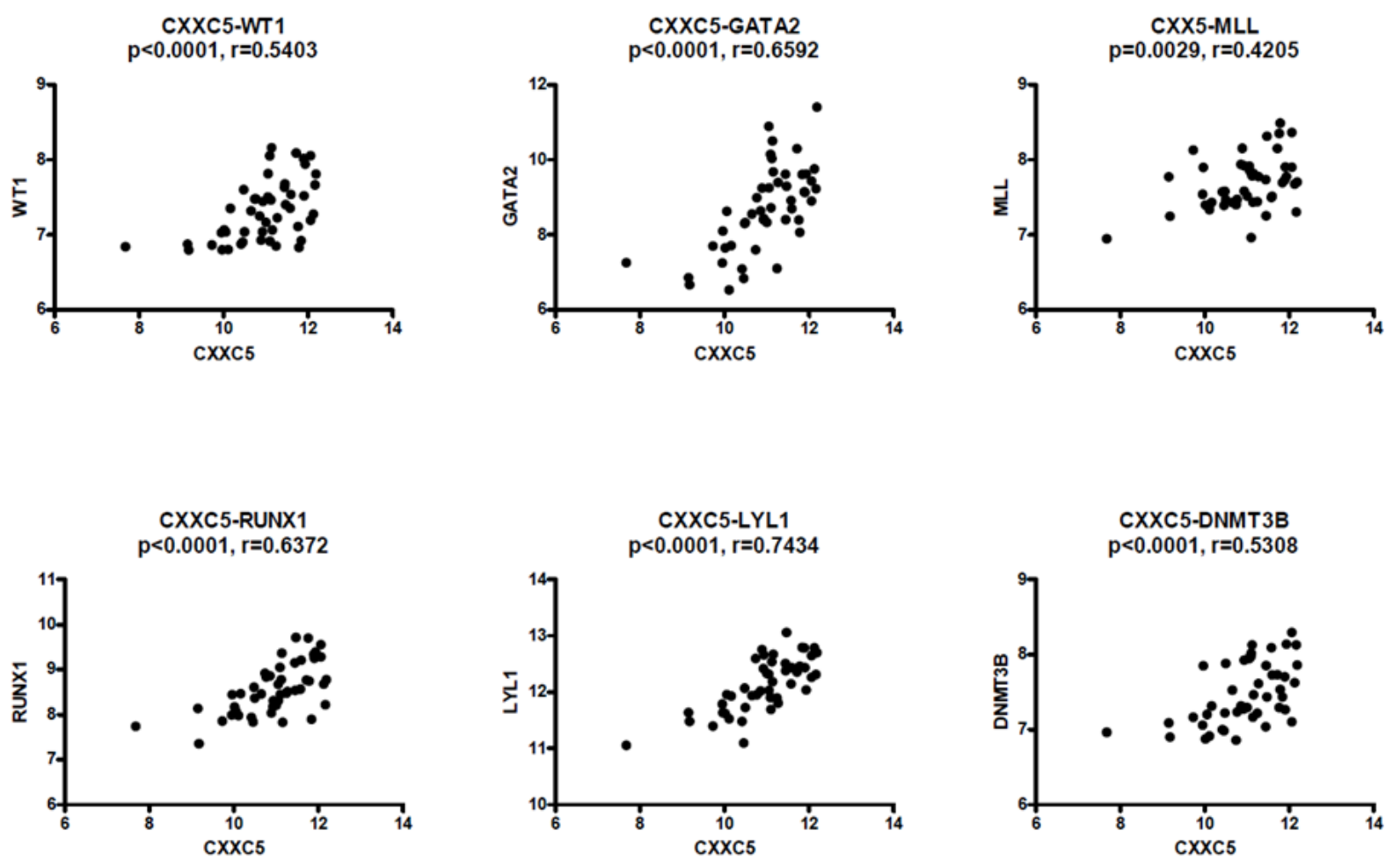

Figure 2: CXXC5/RINF expression is correlated with the expression of several transcriptional regulators in primary human AML cells. Global gene expression analyses were performed for 48 consecutive/unselected AML patients, and we then compared expression of CXXC5 with the expression of WT1, GATA2, MLL, RUNX1, LYL1 and DNMT3B. 
Table 2: Comparison of AML cells showing high and low CXXC5 expression - identification and classification of important proteins encoded by the 571 genes identified from the leading edge in the Gene Set Enrichment Analysis (Supplementary Figure 2). The PANTHER protein classification (Figure 1) identified 4 major classes of proteins, the table describes the most important subclasses within the 4 main protein classes. The main classes are numbered according to the classification in Figure 1.

\section{CLASS 1. RECEPTOR (total protein class hits 68)}

1a G-protein coupled receptor ( $24 / 68$ genes)

The largest subset was chemokine receptors (CCR1/2/7, CXCR1/4, CX3CR1); three adenosine receptors (ADORA3, ADORA2, AADORA2B)

1b Cytokine receptor (36/68 genes)

LILR and CLEC receptors were also included in this term (see 18b below).

Interleukin receptors: IL4R, IL8R1, IL10RB, IL18RAP, IL27 $\beta$

Others: FAS, TNFRSF1B

CLASS 2. HYDROLASES (total protein class hits 53)

\section{2a. Phosphatase $(9 / 53$ genes $)$}

Including the INPPL1 (phosphatidylinositol 3,4,5-triphosphate 5 phosphatase 2) together with A base subunits (ATP6V0E172), one receptor-type (PTPRJ) and one no receptor (PTPN6) tyrosine-protein phosphatase.

\section{2b Proteases (35/53 genes)}

The complement system: C2, CD45, CFB, CFD, CF1, CR1, Cathepsins: CTSA, CTSB, CTSD, CTSG, CTSK, CTSL1, CTSL2, CTSS, CTSZ

Others: Caspase 1, Matrix metalloprotease 9 and 25.

CLASS 3. DEFENSE/IMMUNITY PROTEINS (total protein class hits 53)

3a Immunoglobulin receptor superfamily (25/53 genes)

HLA molecules: HLA-A, HLA-B, HLA-C, HLA-E, HLA-F

C-type lectin receptors (CLEC1A, CLEC5A, CLEC7A), Leukocyte Immunoglobulin Like Receptors (LILRA1-3, LILRB2/3/5).

Others: CD1D, CD4, Face-receptors (FCGR1A, FCGR1B

\section{CLASS 4. SIGNALING MOLECULE (Total protein class hits 48)}

18a Cytokine (23/48 genes), the main subsets being:

Chemokines: CCL2/3/5/16/20/23, CXCL16

Receptor for G-CSF

The Interferon system: IFNA4, IFNA16, IFNB1

The Interleukin system: (i) IL6 and its downstream targets IL6ST and SOCS3; IL1RA, IL17F, IL27RA

Lymphotoxin A and TNF

18b Membrane-bound signaling molecules (17/48 genes), including:

NOTCH2

(LILR and CLEC, see $1 \mathrm{~b}$ above) 
involved endocytic uptake. Finally, the third group included responses to $\mathrm{pH}$ as well as responses to infections (related to Toll like receptor signaling), regulation of inflammation, and regulation of cell shape.

We did an alternative bioinformatical analysis of the 571 genes identified above (Supplementary Figure 2 ); we then used the Panther database and the genes were analyzed with regard to classification of the encoded proteins (Figure 1 left; total protein class hits 800 ). The four main classes had the following characteristics (Table 2):

Defense/immunity proteins. The majority of genes with different expression were C-type lectin-like receptors (CLEC), HLA molecules (especially class I molecules), and leukocyte immunoglobulin-like receptors (LILR). CLECs and HLA-class I molecules seem to have functional interactions [19] and HLA-molecules are ligands for LILR [20].

Hydrolases. The different expression of phosphatidylinositol 3,4,5-triphosphate 5 phosphatase 2 was the only phosphatase suggesting a difference in specific signaling pathways. The most important subset in this class was the hydrolases; differential expression was then seen for several genes encoding members of the complement system, cathepsins that are important for lysosomal functions [21, 22], and the Matrix Metalloprotease 9 that causes proteolytic cleavage of chemokines (e.g. CXCL8, CXCL12) and thereby may be involved in leukemogenesis [23].

Receptors. The functions of several cytokine receptors differed, including both the chemokine and the interleukin system as wells as Fas and the G-CSF and TNF receptors. We also observed altered expression of adenosine receptors that may have a role in regulation of apoptosis in human AML [24, 25].

Signaling molecules. The expression of cytokines is also altered, including members of both the chemokine, interferon and interleukin systems (especially IL6 signaling).

Thus, the major differences between $\mathrm{CXXC} 5^{\mathrm{HIGH}}$ and $\mathrm{CXXC5}^{\mathrm{LOW}}$ AML include the following functional networks (Table 2): (i) HLA-class I-CLEC-LILR; (i) the chemokine-chemokine receptor system (including MMP9); (iii) the interleukin system; (iv) the complement system; and (v) the lysosomal function and thereby possibly also regulation of autophagy and cell viability $[21,22]$.

CXXC5 expression is correlated with the expression of several hematopoietic transcription factors that are associated with adverse prognosis

Similarity profiling was used to further analyze the global gene expression data and we identified the 200 genes whose expression showed the strongest correlation with CXXC5 expression; those genes with a known function according to the PubMed and Gene databases are listed in Supplementary Table 2. A large subset of these genes is important for gene transcription, the largest group being zinc finger proteins and their interacting proteins. Another large subset was genes important for intracellular signaling including cell surface molecules as well as intracellular mediators. Alternatively, we also investigated the functional importance of the proteins encoded by the 200 genes showing the strongest correlation with CXXC5 expression in the similarity profiling analysis. When this analysis was based on the Panther database we confirmed that a majority of the genes encodes proteins that are important for transcriptional regulation (Figure 1, right). The importance of transcriptional regulation was further confirmed by an alternative analysis based on the Reactome database, and this last analysis in addition suggested that the function of SMAD3 and SMAD4 is altered. The SMAD-signaling pathway operates downstream of the transforming growth factor- $\beta$ (TGF- $\beta$ ) superfamily of ligands; it seems to be important for regulation of normal and possibly also leukemic hematopoietic stem cell functions including regulation of proliferation, differentiation and apoptosis [26-32]. Finally, some of the terms from the Gene Set Enrichment Analysis were as expected also detected at a lower frequency in the similarity analysis (see Figure 1, right part).

A subset of AML patients with adverse prognosis shows high expression of certain hematopoietic stem and progenitor cell-associated transcription factors [33-35], especially the heptade SCL, LYL1, LMO2, GATA2, RUNX1, FLI1 and ERG [34]. With regard to this heptade we observed strong correlations between CXXC5 expression and expression of the four genes LYL1 $(\mathrm{p}<0.0001, \mathrm{r}=0.7434)$, GATA2 $(\mathrm{p}<0.0001, \mathrm{r}=0.6592)$, RUNX1 $(\mathrm{p}<0.0001, \mathrm{r}=0.6372)$ and ERG $(\mathrm{p}=0.0212$, $\mathrm{r}=0.3318$ ); the correlations did not reach significance for the two factors SCL ( $\mathrm{p}=0.1076, \mathrm{r}=0.2352)$ and FLI1 $(\mathrm{p}=0.1866, \mathrm{r}=0.3760)$ (Figure 2); and even though CXXC5 expression did not show any significant correlation with the expression of the last factor LMO2 ( $\mathrm{p}=0.4815$, $\mathrm{r}=0.1041$ ) it showed a strong correlation with expression of LYL1 that is necessary for recruitment of LMO2 to DNA [36, 37]. Furthermore, CXXC5 expression also showed significant correlations with the expression of several other transcriptional regulators, including WT1 $(\mathrm{p}<0.0001, \mathrm{r}=0.5403)$, DNMT3B $(\mathrm{p}<0.0001, \mathrm{r}=0.5308)$, MLL $(\mathrm{p}=0.0029, \mathrm{r}=0.4205)$, SPI1 $(\mathrm{p}=0.0001, \mathrm{r}=0.5222)$, MYB $(\mathrm{p}=0.0004, \mathrm{r}=0.4930)$ and GFI1B $(\mathrm{p}=0.0110$, $\mathrm{r}=0.3641)$.

We finally investigated the association between CXXC5 expression and the overall expression profile of the transcription factor heptade. We then analyzed the expression of all 7 transcription factors for the 15 AML patients with the highest and the 15 patients with 
the lowest CXXC5 expression (Figure 3), and we did a clustering analysis of these 30 patients based on the expression profile of the 7 factors. The overall heptade signature separated the patients into two main subsets corresponding to the $\mathrm{CXXC5} 5^{\mathrm{HIGH}}$ and $\mathrm{CXXC}^{\mathrm{LOW}}$ subsets. Thus, clustering analysis shows that $\mathrm{CXXC5/RINF}$ expression shows a strong correlation with several other transcription factors involved in hematopoiesis, including several members of the transcription factor heptade (GATA2, RUNX, ERG, the LM02 recruitment factor LYL1) that is associated with adverse prognosis in AML [35].

\section{High CXXC5 mRNA expression is associated with a stem cell signature that has an adverse prognostic impact}

Eppert et al. [33] identified gene expression signatures for normal hematopoietic and AML stem cells, and three gene subsets were then identified: (i) genes showing differential expression in leukemic stem cells (LSC-related); (ii) genes showing differential expression in normal hematopoietic progenitor/stem cell (HSCrelated) with a subset of these genes also being highly expressed in AML stem cells; and (iii) a subset of genes driving the expression of HSC-related genes in AML stem cell. Thereafter they compared the AML cell expression of these genes for patients with good and adverse prognosis, and based on this comparison they identified 35 genes associated with adverse prognosis. Eight of these genes were among the 650 highest ranked genes in the similarity profile analysis and thus showed very strong correlation with CXXC5 expression (GPR56, ANGPT1, SLC9A7, GOLGA8, TUG1, LOC552889, PIK3C2B, RABGAP1; $\mathrm{p}<0.0001$ for all), and CXXC5 expression showed weaker but still significant correlations $(p<0.05)$ with 18 additional genes (Figure 4). We compared the expression of these 35 genes for our 15 patients with the highest and the 15 patients with the lowest CXXC5 expression (Figure 4). Based on this clustering analysis we identified two main patient subsets including a majority (13 out of 15) $\mathrm{CXXC}^{\mathrm{HIGH}}$ and $\mathrm{CXXC}^{\mathrm{LOW}}$ patients, respectively. Thus, high CXXC5 expression is also associated with this stem cell signature that has an adverse prognostic impact.

\section{$\mathrm{CXXC5}^{\mathrm{HIGH}}$ and $\mathrm{CXXC5}^{\mathrm{LOw}}$ AML cells show only minor differences in their cytokine secretion}

Our GSEA analysis suggested that regulation of cytokine release (especially IL6 and TNF $\alpha$ ) differed between $\mathrm{CXXC}^{\mathrm{HIGH}}$ and $\mathrm{CXXC}^{\mathrm{LOW}}$ patients, and several of the membrane receptors or intracellular pathways showing differential expression are also important for regulation of cytokine release (see Table 2). For this
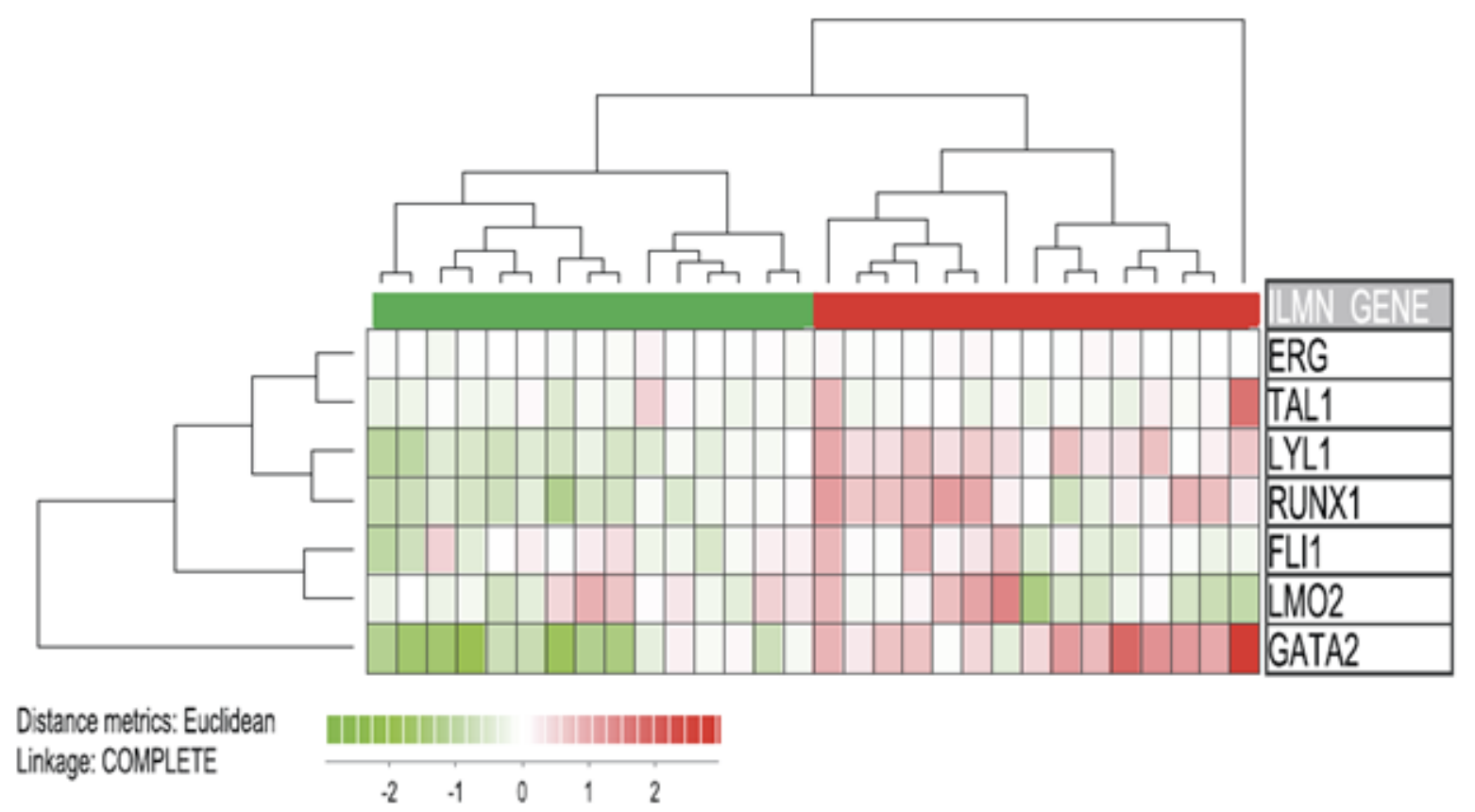

Figure 3: Expression of CXXC5 versus the expression of the transcription factor heptade SCL, LYL1, LMO2, GATA2, RUNX1, FLI1 and ERG. The expression of these transcription factors is associated with adverse prognosis [34]. We compared the 15 patients with the highest and the 15 patients with the lowest CXXC5 expression based on our global gene expression profiling for 48 unselected AML patients. We did a hierarchical clustering analysis; based on this transcription factor signature the clustering analysis identified to major subsets corresponding to the $\mathrm{CXXC} 5^{\mathrm{HIGH}}$ and $\mathrm{CXXC} 5^{\mathrm{LOW}}$ patient subsets. Thus, $\mathrm{CXXC} 5$ expression is not only associated with the expression of single transcription factors but also with the overall heptade signature. 
reason we compared the constitutive cytokine release for the 10 patients in the PCR-analyzed patient cohort with the highest and the 10 patients with the lowest CXXC5 expression in their AML cells. Lenalidomide was also investigated because this drug is used in the treatment of patients with myelodysplastic syndrome (MDS) and the $\operatorname{del}(5 q)$ abnormality that leads to loss of one CXXC5 gene and low CXXC5 expression (1). Firstly, the constitutive cytokine release did not differ between $\mathrm{CXXC} 5^{\mathrm{HIGH}}$ and
$\mathrm{CXXC}^{\text {LOW }}$ patients and showed a similar wide variation for both groups without any statistically significant differences (Supplementary Table 3). Secondly, we also did unsupervised hierarchical clustering analyses; the two groups then differed in their constitutive cytokine release clustering and the most striking difference was a very close chemokine clustering (especially CCL2-4 and IL-8/CXCL8) detected only for CXXC5 ${ }^{\text {LOW }}$ patients (Supplementary Figure 3). The variations between patients

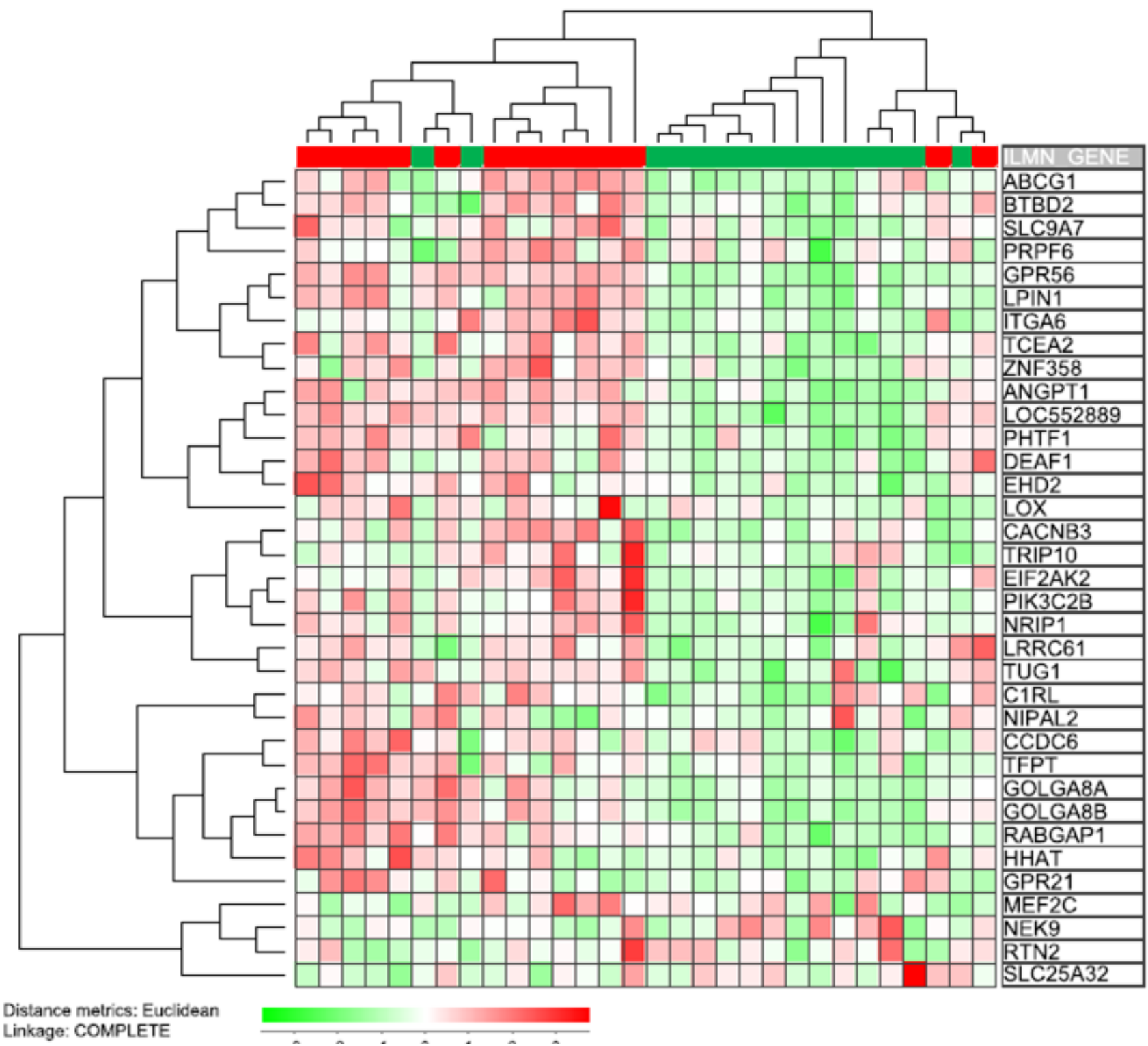

Figure 4: Expression of CXXC5 versus the expression of a stem cell signature associated with adverse prognosis in AML patients receiving intensive chemotherapy [33]. The previous study by Eppert et al identified 35 genes that were expressed by leukemic stem cells and associated with an adverse prognosis. We compared the 15 patients with the highest and the 15 patients with the lowest CXXC5 expression in our global gene expression profiling for 48 unselected AML patients. We did a hierarchical clustering analysis. Based on this analysis of the stem cell signature we identified two main patient subset; one subset included the majority of AML patients showing high CXXC5 expression in their leukemic cells (13 out of 15 patients; left main cluster) whereas the other main subset included the majority of patients with low CXXC5 expression (also 13 out 15 patients). Thus, CXXC5 expression is not only associated with the expression of single stem cell associated genes but also with the overall leukemic stem cell signature. All genes included in this analysis (see right part of figure) showed a statistically significant correlation with CXXC5 expression ( $\mathrm{p}<0.05)$ except for the 9 genes GPR21, LOX, MEF2C, NEK9, NIPAL2, PRPF6, RTN2, SLC25A32, TRIP10. 
could not be explained by differences in spontaneous apoptosis/viability during culture (data not shown). Thirdly, we compared the effect of lenalidomide on the release of individual cytokines (Supplementary Table 4); for the $\mathrm{CXXC5}^{\mathrm{LOW}}$ group lenalidomide caused a significant reduction of IL1 $\beta, \mathrm{TNF} \alpha$ and GM-CSF, whereas for the $\mathrm{CXXC}^{\mathrm{HIGH}}$ group a decrease was seen for IL1 $\beta$, TNF $\alpha$, IL6 and IL1RA. The percentage reduction of the cytokine levels differed significantly between the two groups only for IL6 (48.1\% reduction for CXXC5 $5^{\mathrm{HIGH}}$ versus $78.7 \%$ for $\mathrm{CXXC}^{\mathrm{LOW}}$ patients, Mann Whitney
U-test, $\mathrm{p}=0.0464)$. Our gene expression studies suggested differences in IL6 and TNF $\alpha$ release (Table 2), and this was thus supported by our protein studies. However, we conclude that the differences in cytokine clustering and the lenalidomide-induced alterations should be regarded as minor differences in cytokine release; the main difference between individual patients being the wide variation in cytokine release (more than $10^{4}$-fold for several cytokines, see Supplementary Table 3) that is independent of CXXC5 expression.
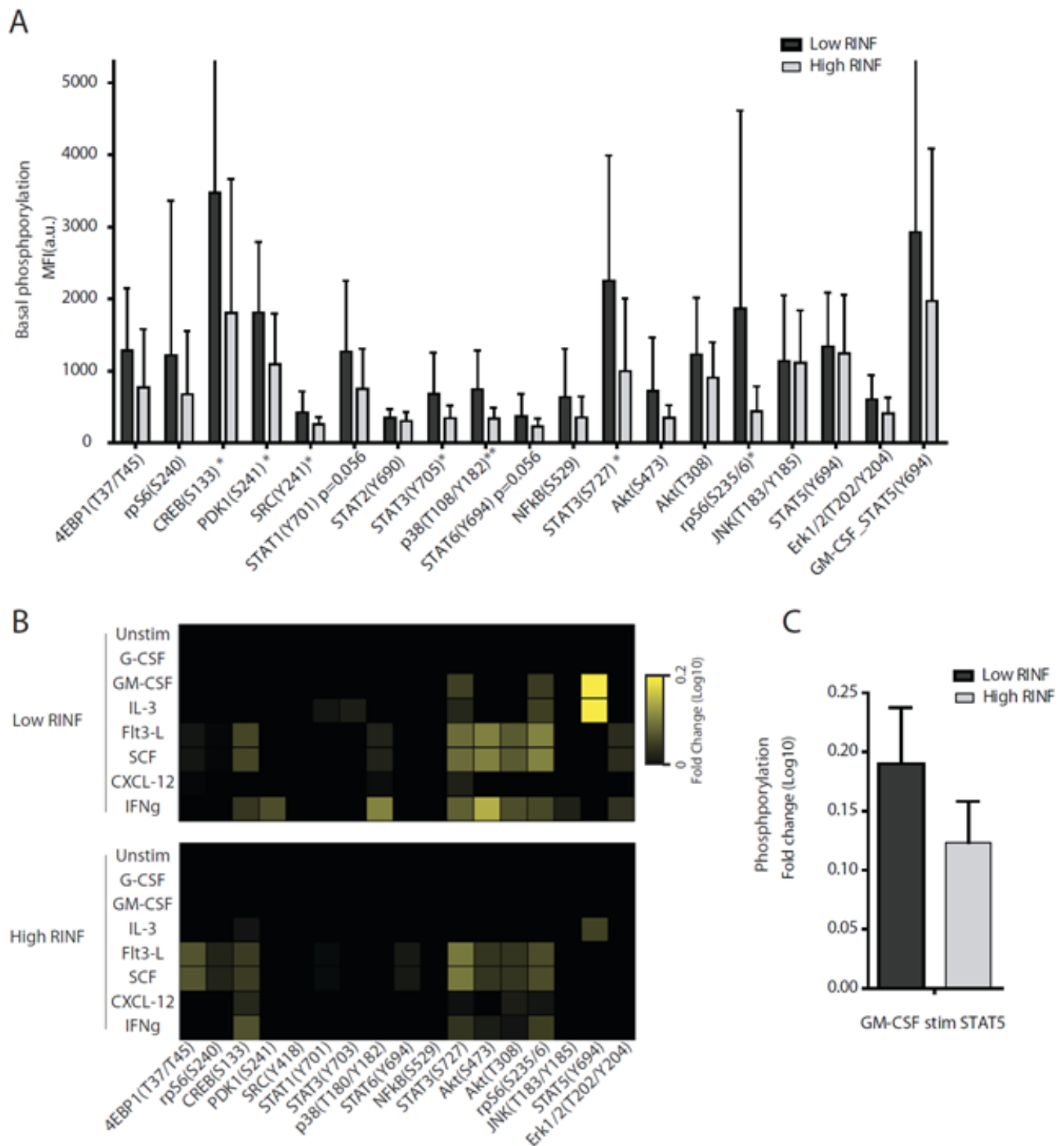

Figure 5: The intracellular phosphorylation status and phospho-responsiveness of primary human AML cells derived from patients with high and low constitutive mRNA CXXC5/RINF expression. A total of 42 patients were included in these studies, and the phosphoprotein status was examined by flow cytometry. (A) The basic phosphorylation status was compared for the 21 patients with the highest and the 21 patients with the lowest CXXC5 expression. The results are presented as the mean and standard deviation for the MFI values. Significant differences between the two groups are indicated in the figure $(* p<0.05, * * p<0.01)$. (B) We then compared the phosphorylation responsiveness for the 7 patients with lowest CXXC5/RINF expression and the 10 patients with the highest CXXC5/RINF mRNA levels. The leukemic cells were cultured with 7 exogenous cytokines (see left margin), and median fold alteration (see right margin) for each cytokine/mediator is presented for each of the two groups. (C) The fold change of STAT5 phosphorylation was also compared for the $21 \mathrm{CXXC}^{\mathrm{LOW}}$ and $\mathrm{CXXC}^{\mathrm{HIGH}}$ patients; these results are presented as the fold change. 
$\mathrm{CXXC5}^{\mathrm{HIGH}}$ and $\mathrm{CXXC5}^{\text {LOW }}$ AML cells differ in their intracellular protein phosphorylation profile, including phosphorylation of several transcriptional regulators

Our global gene expression studies suggest that patients with high and low CXXC5 expression differ in their intracellular signaling. We therefore examined the phosphorylation status of 19 intracellular mediators in primary human AML cells derived from 42 unselected patients in our global gene expression patient cohort. The intracellular mediators and the exogenous cytokines added during incubation were selected based on previous observations. Firstly, the intracellular phosphoprotein networks investigated (pathways or single mediators integrating signaling through several pathways) are important for downstream signaling from growth factor receptors commonly expressed by primary human AML cells $[12,13]$. Secondly, ligation of these growth factor receptors by exogenous cytokines not only initiates alterations in protein phosphorylation but also increases [38-40] primary AML cell proliferation and/or modulates cytokine-dependent proliferation [41] for a majority of patients when tested in standardized in vitro models.

The patients showed an expected wide variation of CXXC5 expression in their AML cells. As explained above all the 19 intracellular mediators can be constitutively phosphorylated and/or become phosphorylated in response to cytokine exposure of primary human AML cells, but our high-throughput flow-cytometry technique required an incubation prior to analysis in culture medium containing insulin and transferrin [12, 13, 42]. This medium was used because it is suitable for extended in vitro culture of primary human AML cells $[43,44]$. Our basal phosphorylation status thus refers to the phosphoprotein profile under the influence of these two mediators but without additional hematopoietic growth factors. The comparison of the basal phosphorylation for the 21 patients with the highest and the 21 patients with the lowest CXXC5 expression showed several differences in intracellular signaling and transcriptional regulation with increased phosphorylation of CREB (S133), PDK1 (S241), Src (Y241), STAT3 (Y705), STAT3 (S727), p38 (Y182) and rpS6 (S235/6) for the CXXC5 ${ }^{\text {LOw }}$ patients (Figure 5A). Several of these mediators are involved in PI3K-Akt-mTOR mediated signaling, including PDK1 [45], Src [46], rpS [47], and the transcription factor CREB that is a downstream target of the pathway [48]. STAT3 can also can be activated by Src in addition to g-protein receptors [49]. Finally, p38 is activated by several cytokines and is an important regulator of hematopoiesis through transcription factor activation [50].

We also did a similar comparison based on the PCR analysis of the qPCR cohort; we then compared the phosphoprotein profiles for the 10 patients with the highest and the 7 patients with the lowest CXXC5 expression. We detected increased phosphorylation also of several additional intracellular mediators for CXXC5 ${ }^{\mathrm{LOW}}$ patients $(\mathrm{p}<0.05$ for all). Firstly, STAT1 (Y701) phosphorylation was increased; this mediator has an overlapping repertoire with STAT3 [49] and is a downstream target of Akt [46]. Secondly, STAT6 (Y694) phosphorylation was increased. STAT6 is activated by IL4/IL13 that reduce the constitutive release of several cytokines by primary human AML cells [51, 52]. STAT6 is also a regulator of normal

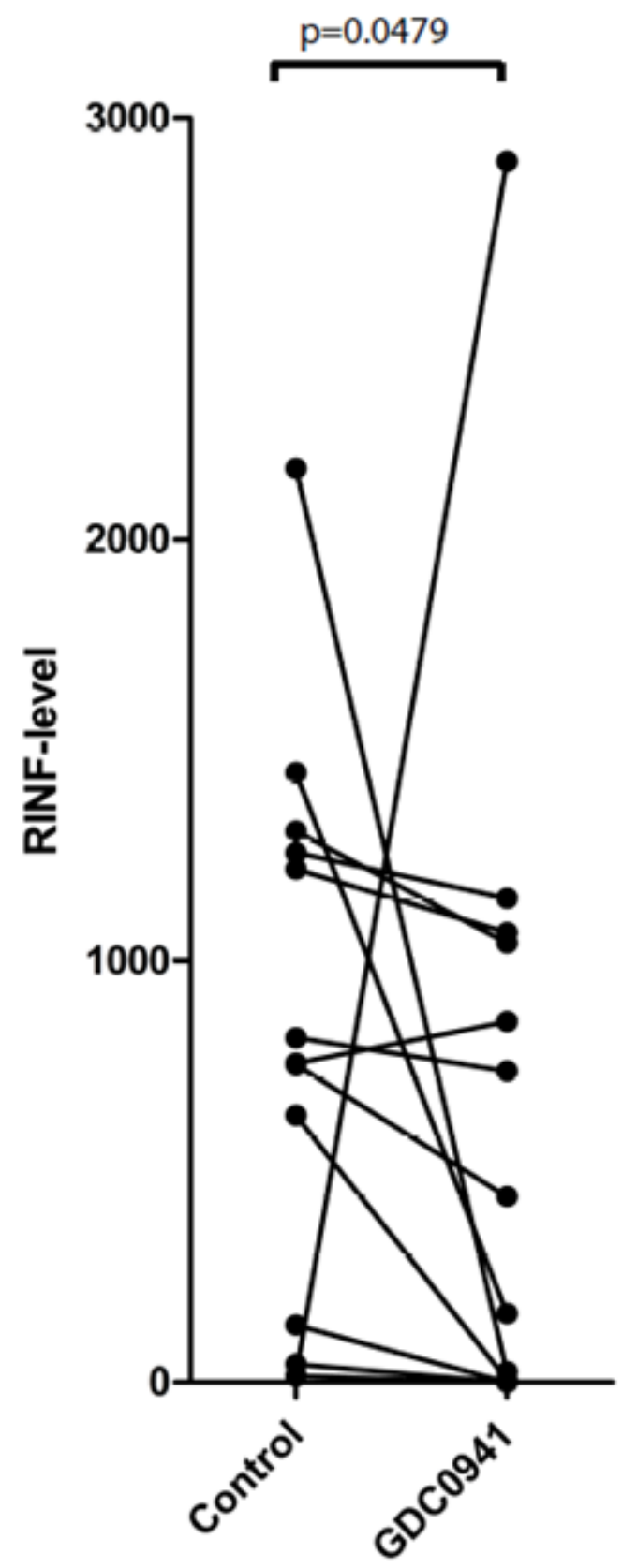

Figure 6: The effect of pharmacological inhibition on CXXC5/RINF mRNA expression levels. Primary human AML cells were cultured with GDC0941 for 5 hours before CXXC5/RINF mRNA levels were compared for drug-free control cultures and drug-containing cultures (Wilcoxon's test for paired samples, $\mathrm{p}=0.0479$ ). 
hematopoiesis [53] and several genetic loci encoding chemokines and adhesion molecules contain STAT6binding motifs [54]. Finally, ERK1/2 phosphorylation (T202/Y204) was altered and CREB is one of its downstream targets [55].

We finally compared the alterations in phosphorylation status when cells were incubated with 7 exogenous cytokines. The overall phosphoresponse differed between $\mathrm{CXXC}^{\mathrm{HIGH}}$ and $\mathrm{CXXC}^{\mathrm{LOW}}$ patients from the PCR cohort, the most striking difference being that only $\mathrm{CXXC}^{\mathrm{LOW}}$ patients showed an increased phosphorylation of STAT3(S727), rpS6(S235/6) and STAT5(Y694) in response to GM-CSF (Figure 5B). Only minor differences were detected for other mediators in response to IL3, Flt3-L, SCF, CXCL12 and IFN $\gamma$. Similar GM-CSF-induced alterations were detected when comparing the $21 \mathrm{CXXC}^{\mathrm{HIGH}}$ and the $21 \mathrm{CXXC}^{\mathrm{LOW}}$ patients in the microarray patient cohort (Figure 5C).

\section{Inhibition of CXXC5 expression by pharmacological intervention}

We investigated pharmacological effects on CXXC5 expression for primary human AML cells after 5 hours of in vitro exposure. CXXC5 expression showed a difference of only borderline significance for the pan-PI3K inhibitor GDC0941 (Figure 6, $\mathrm{p}=0.0479$ ). We observed divergent effects without statistically significant alterations for the PKC agonist PEP005, lenalidomide, the proteasomal inhibitor bortezomib, the mTOR inhibitor rapamycin, the HSP90 inhibitor 17-DMAG, the HSP70 inhibitor VER-155008 and the protein kinase inhibitors PD98059, SB202190 and SP600125 (data not shown). These data suggest that CXXC5 expression integrates signaling through various pathways, and the contribution of each pathway differs between patients.

\section{Effects of CXXC5 knockdown on gene expression in human AML cells}

CXXC5 was knocked down by lentiviral vectors in three different AML cell lines; one vector with pyromycine selection was used for MV4-11 (759 genes upregulated and 744 genes downregulated at least 1.5 fold) and K562 cells (870 genes upregulated and 758 genes downregulated at least 1.5 fold) and another vector based on GFP sorting was used for knockdown in K562 (356 genes upregulated and 457 genes downregulated at least 1.5 fold) and UT7 cells (1291 genes upregulated and 827 genes downregulated at least 1.5 fold). CXX5 knockdown was documented both at the mRNA and protein level for all experiments. These genes were compared with the 50 genes showing highest mRNA expression in the $\mathrm{CXXC}^{\mathrm{HIGH}}$ and $\mathrm{CXXC5} 5^{\mathrm{LOW}}$ patient subset (see Supplementary Tables 1 and 2).
Global gene expression profiles were compared for cells transfected with knock-down vectors and emty control vectors. Four genes were identified according to the following criteria: (i) being among the 50 genes with highest expression in $\mathrm{CXXC5}^{\text {HIGH/LOW }}$ patients (Supplementary Tables 5 and 6); and showing either (iia) $>2$-fold alteration after CXXC5 knockdown for one cell line or (iib) $>1.5$-fold alteration for two different cell lines. All four genes showed high levels for $\mathrm{CXXC}^{\mathrm{HIGH}}$ patients increased levels after CXXC5 knockdown, and their relevance for carcinogenesis/leukemogenesis is described in detail in Suppl. Table 7 and summarized below.

Increased levels of the potential tumor suppressor gene TSC22D1. This gene (TSC22 domain family, member 1) shows increased levels after CXXC5 knockdown and encodes a transcriptional regulator [56] that is a potential tumor suppressor in human AML [57]; it can also contribute to induction of apoptosis in human gastric and breast cancer cells and increase cancer cell sensitivity to anticancer drugs [56] and radiation [58].

Increased levels of the cell cycle regulator SEPP1. The encoded mediator (Selenoprotein P.plasma.1) is a secreted glycoprotein containing extracellular selenium [59]. Selenium and its metabolites are involved in regulation of apoptosis and proliferation/cell cycle progression [60].

Increased expression of the receptor for the Stem cell factor (KIT) and for Angiopoietin 1 (ANGPT1). KIT shows increased levels and encodes CD117 that is expressed by primary human AML cells for most patients but its expression has no prognostic impact for AML patients receiving intensive chemotherapy [61]. ANGPT1 (Angiopoietin 1) is a Tie2 agonist that shows increased expression in $\mathrm{CXXC} 5^{\mathrm{HIGH}}$ cells. Angiopoietin 1 is a regulator of angiogenesis without any prognostic impact by itself in human AML, whereas extracellular levels (serum, bone marrow plasma) of the potential Tie2 antagonist Angiopoietin 2 has an adverse prognostic impact in human AML [62-64]. Finally, ANGP1 is also a member of the leukemic stem cell gene expression signature that has been associated with adverse prognosis in human AML [33]. The extracellular release of Angiopoietin 1 showed a wide variation during in vitro culture (median $37 \mathrm{pg} / \mathrm{ml}$, range $<0.5 \mathrm{pg} / \mathrm{ml}$ to 2135 $\mathrm{pg} / \mathrm{ml}$ ) and a correlation was seen between the level of Angiopoietin $1 \mathrm{mRNA}$ expression and the level of protein release $(\mathrm{p}=0.001)$.

The expression of the transcriptional regulators showing correlated mRNA expression with CXXC5 was not altered by the knockdown (see above). 


\section{CXXC5 expression increases during progression of chronic myeloid leukemia to blast phase}

We previously described that CXXC5 is expressed in AML as well as acute lymphoblastic leukemia cells [4]. In our present study we compared CXXC5 expression in chronic myeloid leukemia cells; we then used previously published global gene expression data [65]. CXXC5 expression was low for CML bone marrow cells in chronic phase, the levels increased during accelerated phase and were highest for patients in blast phase (Fig. 7). Thus, high/increasing CXXC5 expression is associated with more aggressive disease not only in AML but also in CML.

\section{DISCUSSION}

The CXXC5 gene seems important during both normal and leukemic hematopoiesis [2]. High expression in the leukemic cells is an independent adverse prognostic factor in AML [5] and possibly associated with adverse prognosis also in other myeloproliferative diseases, e.g. CML [66].

CXXC5 encodes a transcriptional regulator [3]. Our present studies suggest that this protein is a part of a larger transcription-regulatory network that differs between $\mathrm{CXXC}^{\mathrm{LOW}}$ and $\mathrm{CXXC} 5^{\mathrm{HIGH}}$ patients and includes several stem cell associated transcription factors as well as a heptade of transcription factors associated with an adverse prognosis in human AML [34]. Our bioinformatical analyses demonstrated that CXXC5 expression showed a strong association both to (i) the overall expression profiles of the transcription factor heptade associated with adverse prognosis (Figure 3); and (ii) the overall signature of 35 stem cell-associated genes used to identify AML patients with high-risk disease (Figure 4). CXXC5 expression levels also showed significant correlation with several genes included both in the transcription factor heptade and in the stem cell gene expression profile. Thus, the association between high CXXC5 expression and adverse prognosis is seen in a biological context of a specific transcription-regulatory network and an AML stem cell-associated expression signature. The hypothesis that $\mathrm{CXXC5}$ is a part of a larger transcription-regulatory network is also supported by our similarity gene expression analysis and the corresponding protein function analysis (Figure 1).

Our comparison of gene expression profiles in contrasting $\mathrm{CXXC}^{\mathrm{HIGH}}$ and $\mathrm{CXXC}^{\mathrm{LOW}}$ patients identified 571 genes with different expression (Supplementary Figure 2). The analysis of corresponding protein functions suggests that these two contrasting groups show major differences with regard to communication between cells, i.e. expression of various cell surface molecules (including cytokine receptors) and release of soluble mediators (Figure 1, Table 2). However, there was also an overlap between protein functions identified through the CXXC5 similarity expression analysis and the GSEA analysis of contrasting patient subsets (Figure 1, left part).

We compared the constitutive cytokine release for primary human AML cells with high and low CXXC5 expression but could not detect any difference when comparing single cytokine levels (Supplementary Table 3) but only with regard to cytokine clustering (Supplementary Figure 3). The effect of lenalidomide on cytokine release

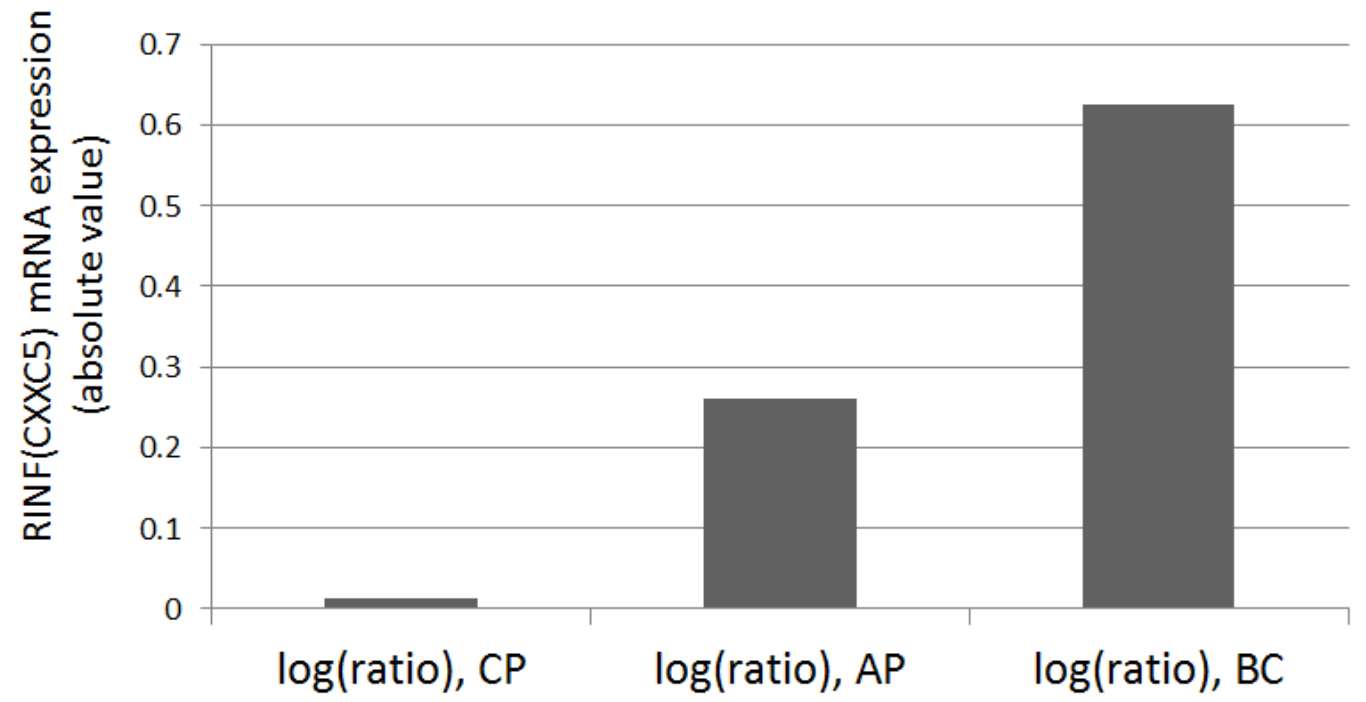

Figure 7; CXXC5/RINF is increased during the progression of chronic myeloid leukemia from chronic phase to blast crisis. The microarray data have been performed by Radich JP et al. [65]. The CXXC5/RINF gene expression data were extracted from a gene list (supporting table 4 or 10423Table4.xls) available online at the PNAS website (http://www.pnas.org/content/103/8/2794/suppl/ DC1). CP: chronic phase $(n=42)$, AP: accelerated phase by blast count criteria $(n=9)$ or by the occurrence of additional clonal cytogenetic changes $(\mathrm{n}=8)$, BC: blast crisis $(\mathrm{n}=28)$. 
also differed between the subsets, and these effects could not be explained by a nonspecific effect secondary to altered viability because a similar effect on all cytokines would then be expected. However, the wide variation in constitutive release is definitely the most important difference between AML patients and this variation is similar for $\mathrm{CXXC}^{\mathrm{HIGH}}$ and $\mathrm{CXXC5}^{\mathrm{LOW}}$ patients; the differences in cytokine clustering and lenalidomide effects should only be regarded as minor differences.

We compared the intracellular phosphoprotein status for $\mathrm{CXXC}^{\mathrm{HIGH}}$ and $\mathrm{CXXC}^{\text {LOW }}$ AML cells. Our high-throughput technique requires an incubation step for antibody binding [14]; we then used a medium suitable for immature hematopoietic cells and containing insulin and transferrin but no hematopoietic growth factors [43, 44] and we refer to this as basal phosphorylation status. In addition we compared growth factor-induced alterations of protein phosphorylation. The low-risk $\mathrm{CXXC5}^{\mathrm{LOW}}$ patients showed increased basal phosphorylation of several mediators. Additional differences were induced by exogenous growth factors, especially GM-CSF/ IL3-induced increase of STAT5 phosphorylation. Thus, variation in CXXC5 expression is associated with differences in intracellular signaling targeting downstream transcription factors.

Our studies suggest that signaling though PI3KAkt is important for CXXC5 expression, and several of the mediators showing different phosphorylation for $\mathrm{CXXC}^{\mathrm{HIGH}}$ and $\mathrm{CXXC}^{\mathrm{LOW}}$ patients are downstream targets to PI3K-Akt-mTOR (see above). Some of the genes identified in the CXXC5 similarity profiling are also important for this pathway (Supplementary Table 2A). All these observations suggest that the pathway is important for regulation of CXXC5 expression. Finally, pharmacological inhibition of other intracellular pathways had divergent effects, these observations then being consistent with the hypothesis that regulation of CXXC5 mRNA expression differs between patients and depends on several/various intracellular signaling pathways.

Previous studies suggest that high constitutive signaling through the PI3K-Akt-mTOR pathway [67, 68] and activation of its downstream target STAT3 [69] is associated with adverse prognosis in human AML. However, a recent study suggested that AML patients are heterogeneous and signaling through this pathway can cause growth inhibition as well as growth enhancement in primary AML cells [70]. STAT3 shows an extensive and cell type-dependent variation in its preference to potential DNA binding sites [71, 72], and a similar variation between biologically heterogeneous AML patients may explain the different biological effects of PI3K-Akt-mTOR-STAT3 signaling between AML patients [73]. Furthermore, the possible prognostic impact of STAT3 activation in human AML is also controversial. Benekli et al. [69] described an association between high constitutive STAT3 activation (i.e. high Y705 phosphorylation) and adverse prognosis, whereas a recent study described improved survival for patients showing high STAT3 Y705 and S727 phosphorylation in their AML cells in response to cytokine stimulation [74]. This last observation is consistent with our present observation of an association between high STAT3 phosphorylation for lowrisk $\mathrm{CXXC5}^{\mathrm{LOW}}$ patients. One possible hypothesis for these apparently conflicting observations could be that the prognostic impact of STAT3 in human AML is not (only) mediated by its phosphorylated form, but by the unphosphorylated form and its interaction with NFкB signaling [72]. This hypothesis is also consistent with the previously described associations between phosphorylated forms of STAT3 and antiproliferative/proapoptotic effects in human cancer cells [75] and stem cells [76], during murine carcinogenesis [77] and in STAT3 knock-down models [78].

STAT5 phosphorylation/activation can also mediate proapoptotic effects through activation of growth inhibitory and proapoptotic genes depending on its biological context [79], and this may also explain the association between the $\mathrm{CXXC}^{\mathrm{LOW}}$ phenotype and increased STAT5 phosphorylation after GM-CSF/IL3 exposure. Finally, increased CREB phosphorylation was observed for $\mathrm{CXXC}^{\mathrm{LOW}}$ patients, but this may be less important because animal models suggest that CREB only contributes to the AML phenotype but is not sufficient for leukemic transformation [48]. Thus, the increased phosphorylation of these intracellular mediators for lowrisk $\mathrm{CXXC5}^{\text {LOW }}$ patients may contribute to the good prognosis for these patients due to the biological context, i.e. crosstalk between pathways or interactions with other transcriptional regulators [80].

Based on the knockdown experiments and analysis of global gene expression profiles (Supplementary Tables 5 and 6) we identified four genes that both were altered by CXXC5 knockdown and whose expression showed a strong correlation with $\mathrm{CXXC5}$ expression in primary AML cells. These genes were increased by CXXC5 knockdown; this can be explained by an inhibitory effect of CXXC5/RINF on their expression and stimulatory effect(s) by other transcriptional regulators that show strong correlation with CXXC5 expression (see above). Those genes showing high expression in $\mathrm{CXXC}^{\mathrm{HIGH}}$ primary human AML cells and being significantly altered (i.e. increased ) after CXXC5 knockdown included one potential tumor suppressor (TSC22), the cytokine Angiopoietin 1, a selenium transport protein and the hematopoietic growth factor receptor KIT. The three first may be important for regulation of apoptosis or cell cycle progression in human malignant cells, whereas the KIT receptor mediates growth-enhancing effects in human AML cells although it does not have any impact on chemosensitivity/prognosis (Supplementary Table 7). Thus, these knockdown experiments further support a role of CXXC5/RINF in AML chemosensitivity. 
To summarize, CXXC5 expression shows a wide variation in primary human AML cells and high levels are associated with an adverse prognosis. Our present results suggest that CXXC5 integrates several intracellular signaling events and thereby have effects of several steps in regulation of leukemogenesis or chemosensitivity in human AML.

\section{ACKNOWLEDGEMENTS}

The study received financial support from the Norwegian Cancer Society (ØB, HF, KMH, BTG) and the Aurora exchange program for the French-Norwegian collaborative project (ØB, FP). FP received funding support from Ligue Nationale Contre le Cancer, and Cochin Institute. AA was supported by Ligue Nationale Contre le Cancer, Société Française d'Hématologie, and Fondation pour la Recherche Médicale. We thank Pierre de la Grange (Genosplice), Mylène Bohec, Sébastien Jacques, and Florent Dumont (Genomic platform of Cochin Insitute, Paris, France) for HTA2 microarray experiments, data analysis, and MIAME (Minimum Information About a Microarray Experiment) deposit into array-express databank. We are grateful to Hélène Babski and Gabriel Matherat for their technical help and scientific discussions.

\section{REFERENCES}

1. Boultwood J, Pellagatti A, McKenzie AN and Wainscoat JS. Advances in the 5q- syndrome. Blood. 2010; 116(26):58035811.

2. Pendino F, Nguyen E, Jonassen I, Dysvik B, Azouz A, Lanotte M, Segal-Bendirdjian E and Lillehaug JR. Functional involvement of RINF, retinoid-inducible nuclear factor (CXXC5), in normal and tumoral human myelopoiesis. Blood. 2009; 113(14):3172-3181.

3. Kim HY, Yang DH, Shin SW, Kim MY, Yoon JH, Kim S, Park HC, Kang DW, Min D, Hur MW and Choi $\mathrm{KY}$. CXXC5 is a transcriptional activator of Flk-1 and mediates bone morphogenic protein-induced endothelial cell differentiation and vessel formation. FASEB J. 2014; 28(2):615-626.

4. Astori A, Fredly H, Aloysius TA, Bullinger L, Mansat-De Mas V, de la Grange P, Delhommeau F, Hagen KM, Recher C, Dusanter-Fourt I, Knappskog S, Lillehaug JR, Pendino F and Bruserud O. CXXC5 (retinoid-inducible nuclear factor, RINF) is a potential therapeutic target in high-risk human acute myeloid leukemia. Oncotarget. 2013; 4(9):1438-1448.

5. Kühnl A, Valk PJM, Sanders MA, Hills RK, Mills KI, Gale RE, Kaiser M, Dillon R, Joannides M, Ivey A, Gilkes AF, Haferlach T, Schnittger S, Duprez E, Linch D, Delwel R, et al. Downregulation Of The Wnt Inhibitor CXXC5 Predicts a Better Prognosis In Acute Myeloid Leukemia. Blood. 2013; 122(21):52.
6. Bruserud O, Hovland R, Wergeland L, Huang TS and Gjertsen BT. Flt3-mediated signaling in human acute myelogenous leukemia (AML) blasts: a functional characterization of Flt3-ligand effects in AML cell populations with and without genetic Flt3 abnormalities. Haematologica. 2003; 88(4):416-428.

7. Hatfield KJ, Hovland R, Oyan AM, Kalland KH, Ryningen A, Gjertsen BT and Bruserud O. Release of angiopoietin-1 by primary human acute myelogenous leukemia cells is associated with mutations of nucleophosmin, increased by bone marrow stromal cells and possibly antagonized by high systemic angiopoietin-2 levels. Leukemia. 2008; 22(2):287-293.

8. Bruserud $\mathrm{O}$, Gjertsen BT and von Volkman HL. In vitro culture of human acute myelogenous leukemia (AML) cells in serum-free media: studies of native AML blasts and AML cell lines. J Hematother Stem Cell Res. 2000; 9(6):923-932.

9. Stapnes C, Ryningen A, Hatfield K, Oyan AM, Eide GE, Corbascio M, Kalland KH, Gjertsen BT and Bruserud O. Functional characteristics and gene expression profiles of primary acute myeloid leukaemia cells identify patient subgroups that differ in susceptibility to histone deacetylase inhibitors. Int J Oncol. 2007; 31(6):1529-1538.

10. Fredly H, Ersvaer E, Gjertsen BT and Bruserud O. Immunogenic apoptosis in human acute myeloid leukemia (AML): primary human AML cells expose calreticulin and release heat shock protein (HSP) 70 and HSP90 during apoptosis. Oncol Rep. 2011; 25(6):1549-1556.

11. Stapnes C, Doskeland AP, Hatfield K, Ersvaer E, Ryningen A, Lorens JB, Gjertsen BT and Bruserud O. The proteasome inhibitors bortezomib and PR-171 have antiproliferative and proapoptotic effects on primary human acute myeloid leukaemia cells. Br J Haematol. 2007; 136(6):814-828.

12. Irish JM, Hovland R, Krutzik PO, Perez OD, Bruserud O, Gjertsen BT and Nolan GP. Single cell profiling of potentiated phospho-protein networks in cancer cells. Cell. 2004; 118(2):217-228.

13. Skavland J, Jorgensen KM, Hadziavdic K, Hovland R, Jonassen I, Bruserud O and Gjertsen BT. Specific cellular signal-transduction responses to in vivo combination therapy with ATRA, valproic acid and theophylline in acute myeloid leukemia. Blood Cancer J. 2011; 1:e4.

14. Skavland J, Reikvam $\mathrm{H}$ and Bruserud Ø. Survival Stratification In Acute Myeloid Leukemia By Single Cell Signal Profiling. Blood. 2013; 122(21):2625.

15. Gandoura S, Weiss E, Rautou PE, Fasseu M, Gustot T, Lemoine F, Hurtado-Nedelec M, Hego C, Vadrot N, Elkrief L, Letteron P, Tellier Z, Pocidalo MA, Valla D, Lebrec $\mathrm{D}$, Groyer A, et al. Gene- and exon-expression profiling reveals an extensive LPS-induced response in immune cells in patients with cirrhosis. J Hepatol. 2013; 58(5):936-948.

16. Wang E, Aslanzadeh V, Papa F, Zhu H, de la Grange P and Cambi F. Global profiling of alternative splicing events and gene expression regulated by hnRNPH/F. PLoS One. 2012; 
7(12):e51266

17. de la Grange P, Dutertre M, Martin N and Auboeuf D. FAST DB: a website resource for the study of the expression regulation of human gene products. Nucleic Acids Res. 2005; 33(13):4276-4284.

18. de la Grange P, Dutertre M, Correa M and Auboeuf D. A new advance in alternative splicing databases: from catalogue to detailed analysis of regulation of expression and function of human alternative splicing variants. BMC Bioinformatics. 2007; 8:180.

19. Cassidy SA, Cheent KS and Khakoo SI. Effects of Peptide on NK cell-mediated MHC I recognition. Front Immunol. 2014; 5:133.

20. Lichterfeld M and Yu XG. The emerging role of leukocyte immunoglobulin-like receptors (LILRs) in HIV-1 infection. J Leukoc Biol. 2012; 91(1):27-33.

21. Gondi CS and Rao JS. Cathepsin B as a cancer target. Expert Opin Ther Targets. 2013; 17(3):281-291.

22. Repnik U, Stoka V, Turk V and Turk B. Lysosomes and lysosomal cathepsins in cell death. Biochim Biophys Acta. 2012; 1824(1):22-33.

23. Hatfield KJ, Reikvam H and Bruserud O. The crosstalk between the matrix metalloprotease system and the chemokine network in acute myeloid leukemia. Curr Med Chem. 2010; 17(36):4448-4461.

24. Lee EJ, Min HY, Chung HJ, Park EJ, Shin DH, Jeong LS and Lee SK. A novel adenosine analog, thio-Cl-IB-MECA, induces G0/G1 cell cycle arrest and apoptosis in human promyelocytic leukemia HL-60 cells. Biochem Pharmacol. 2005; 70(6):918-924.

25. Schneider C, Wiendl $\mathrm{H}$ and Ogilvie A. Biphasic cytotoxic mechanism of extracellular ATP on U-937 human histiocytic leukemia cells: involvement of adenosine generation. Biochim Biophys Acta. 2001; 1538(2-3):190205.

26. Elton TS, Selemon H, Elton SM and Parinandi NL. Regulation of the MIR155 host gene in physiological and pathological processes. Gene. 2013; 532(1):1-12.

27. Zhang Y and Derynck R. Transcriptional regulation of the transforming growth factor-beta -inducible mouse germ line Ig alpha constant region gene by functional cooperation of Smad, CREB, and AML family members. J Biol Chem. 2000; 275(22):16979-16985.

28. Lan Y and Yang X. The role of Smad signaling in vascular and hematopoietic development revealed by studies using genetic mouse models. Science China Life sciences. 2010; 53(4):485-489.

29. Blank U and Karlsson S. The role of Smad signaling in hematopoiesis and translational hematology. Leukemia. 2011; 25(9):1379-1388.

30. Larsson $\mathrm{J}$ and Karlsson S. The role of Smad signaling in hematopoiesis. Oncogene. 2005; 24(37):5676-5692.

31. Ruscetti FW, Akel S and Bartelmez SH. Autocrine transforming growth factor-beta regulation of hematopoiesis: many outcomes that depend on the context. Oncogene. 2005; 24(37):5751-5763.

32. Liu B and Mao N. Smad5: signaling roles in hematopoiesis and osteogenesis. Int J Biochem Cell Biol. 2004; 36(5):766770 .

33. Eppert K, Takenaka K, Lechman ER, Waldron L, Nilsson B, van Galen P, Metzeler KH, Poeppl A, Ling V, Beyene J, Canty AJ, Danska JS, Bohlander SK, Buske C, Minden $\mathrm{MD}$, Golub TR, et al. Stem cell gene expression programs influence clinical outcome in human leukemia. Nat Med. 2011; 17(9):1086-1093.

34. Diffner E, Beck D, Gudgin E, Thoms JA, Knezevic K, Pridans C, Foster S, Goode D, Lim WK, Boelen L, Metzeler $\mathrm{KH}$, Micklem G, Bohlander SK, Buske C, Burnett A, Ottersbach K, et al. Activity of a heptad of transcription factors is associated with stem cell programs and clinical outcome in acute myeloid leukemia. Blood. 2013; 121(12):2289-2300.

35. Wilson NK, Foster SD, Wang X, Knezevic K, Schutte J, Kaimakis P, Chilarska PM, Kinston S, Ouwehand WH, Dzierzak E, Pimanda JE, de Bruijn MF and Gottgens B. Combinatorial transcriptional control in blood stem/ progenitor cells: genome-wide analysis of ten major transcriptional regulators. Cell Stem Cell. 2010; 7(4):532544.

36. Curtis DJ, Salmon JM and Pimanda JE. Concise review: Blood relatives: formation and regulation of hematopoietic stem cells by the basic helix-loop-helix transcription factors stem cell leukemia and lymphoblastic leukemia-derived sequence 1. Stem Cells. 2012; 30(6):1053-1058.

37. Baer R. TAL1, TAL2 and LYL1: a family of basic helixloop-helix proteins implicated in T cell acute leukaemia. Semi Cancer Biol. 1993; 4(6):341-347.

38. Bruserud $\mathrm{O}$ and Ulvestad E. Effects of gamma-irradiation on acute myelogenous leukemia blasts: in vitro studies of proliferation, constitutive cytokine secretion, and accessory cell function during $\mathrm{T}$ cell activation. J Hematother Stem Cell Res. 1999; 8(4):431-441.

39. Bruserud O, Gjertsen BT, Foss B and Huang TS. New strategies in the treatment of acute myelogenous leukemia (AML): in vitro culture of aml cells--the present use in experimental studies and the possible importance for future therapeutic approaches. Stem Cells. 2001; 19(1):1-11.

40. Reikvam H, Oyan AM, Kalland KH, Hovland R, Hatfield $\mathrm{KJ}$ and Bruserud O. Differences in proliferative capacity of primary human acute myelogenous leukaemia cells are associated with altered gene expression profiles and can be used for subclassification of patients. Cell Prolif. 2013; 46(5):554-562.

41. Ersvaer E, Skavland J, Ulvestad E, Gjertsen BT and Bruserud O. Effects of interferon gamma on native human acute myelogenous leukaemia cells. Cancer Immunol Immunother. 2007; 56(1):13-24.

42. Irish JM, Anensen N, Hovland R, Skavland J, Borresen- 
Dale AL, Bruserud O, Nolan GP and Gjertsen BT. Flt3 Y591 duplication and Bcl-2 overexpression are detected in acute myeloid leukemia cells with high levels of phosphorylated wild-type p53. Blood. 2007; 109(6):25892596.

43. Salem M, Delwel R, Touw I, Mahmoud L and Lowenberg B. Human AML colony growth in serum-free culture. Leuk Res. 1988; 12(2):157-165.

44. Bruserud O, Frostad S and Foss B. In vitro culture of acute myelogenous leukemia blasts: a comparison of four different culture media. J Hematother. 1999; 8(1):63-73.

45. Bayascas JR. PDK1: the major transducer of PI 3-kinase actions. Cur Topic Microbiol Immunol. 2010; 346:9-29.

46. Byeon SE, Yi YS, Oh J, Yoo BC, Hong S and Cho JY. The role of Src kinase in macrophage-mediated inflammatory responses. Med Inflam. 2012; 2012:512926.

47. Magnuson B, Ekim B and Fingar DC. Regulation and function of ribosomal protein S6 kinase (S6K) within mTOR signalling networks. Biochem J. 2012; 441(1):1-21.

48. Cho EC, Mitton B and Sakamoto KM. CREB and leukemogenesis. Crit Rev Oncog. 2011; 16(1-2):37-46.

49. Fagard R, Metelev V, Souissi I and Baran-Marszak F. STAT3 inhibitors for cancer therapy: Have all roads been explored? Jak-Stat. 2013; 2(1):e22882.

50. Oeztuerk-Winder F and Ventura JJ. The many faces of $\mathrm{p} 38$ mitogen-activated protein kinase in progenitor/stem cell differentiation. Biochem J. 2012; 445(1):1-10.

51. Bruserud $\varnothing$. IL-4, IL-10 and IL-13 in acute myelogenous leukemia. Cytokines Cell Mol Ther. 1998; 4(3): 187-198.

52. Bruserud O. Effects of interleukin-13 on cytokine secretion by human acute myelogenous leukemia blasts. Leukemia. 1996; 10(9):1497-1503.

53. Bruns HA and Kaplan MH. The role of constitutively active Stat6 in leukemia and lymphoma. Crit Rev Oncol/Hematol. 2006; 57(3):245-253.

54. Hebenstreit D, Wirnsberger G, Horejs-Hoeck J and Duschl A. Signaling mechanisms, interaction partners, and target genes of STAT6. Cytokine \& Growth Fact Rev. 2006; 17(3):173-188.

55. De Luca A, Maiello MR, D'Alessio A, Pergameno M and Normanno N. The RAS/RAF/MEK/ERK and the PI3K/ AKT signalling pathways: role in cancer pathogenesis and implications for therapeutic approaches. Exp Opini Ther Targ. 2012; 16 Suppl 2:S17-27.

56. Kawamata H, Fujimori $\mathrm{T}$ and Imai Y. TSC-22 (TGFbeta stimulated clone-22): a novel molecular target for differentiation-inducing therapy in salivary gland cancer. Curr Cancer Drug Targets. 2004; 4(6):521-529.

57. Lu Y, Kitaura J, Oki T, Komeno Y, Ozaki K, Kiyono M, Kumagai H, Nakajima H, Nosaka T, Aburatani H and Kitamura T. Identification of TSC-22 as a potential tumor suppressor that is upregulated by Flt3-D835V but not Flt3ITD. Leukemia. 2007; 21(11):2246-2257.

58. Hino S, Kawamata H, Omotehara F, Uchida D, Miwa
Y, Begum NM, Yoshida H, Sato $M$ and Fujimori T. Cytoplasmic TSC-22 (transforming growth factor-betastimulated clone-22) markedly enhances the radiation sensitivity of salivary gland cancer cells. Biochem Biophys Res Commun. 2002; 292(4):957-963.

59. Burk RF and Hill KE. Selenoprotein P-expression, functions, and roles in mammals. Biochim Biophys Acta. 2009; 1790(11):1441-1447.

60. Zeng H. Selenium as an essential micronutrient: roles in cell cycle and apoptosis. Molecules. 2009; 14(3):1263-1278.

61. Schwartz S, Heinecke A, Zimmermann M, Creutzig U, Schoch C, Harbott J, Fonatsch C, Loffler H, Buchner T, Ludwig WD and Thiel E. Expression of the C-kit receptor (CD117) is a feature of almost all subtypes of de novo acute myeloblastic leukemia (AML), including cytogenetically good-risk AML, and lacks prognostic significance. Leuk Lymphoma. 1999; 34(1-2):85-94.

62. Kümpers P, Koenecke C, Hecker H, Hellpap J, Horn R, Verhagen W, Buchholz S, Hertenstein B, Krauter J, Eder M, David S, Gohring G, Haller H and Ganser A. Angiopoietin-2 predicts disease-free survival after allogeneic stem cell transplantation in patients with highrisk myeloid malignancies. Blood. 2008; 112(5):2139-2148.

63. Lee CY, Tien HF, Hu CY, Chou WC and Lin LI. Marrow angiogenesis-associated factors as prognostic biomarkers in patients with acute myelogenous leukaemia. Br J Cancer. 2007; 97(7):877-882.

64. Schliemann C, Bieker R, Thoennissen N, Gerss J, Liersch R, Kessler T, Buchner T, Berdel WE and Mesters RM. Circulating angiopoietin-2 is a strong prognostic factor in acute myeloid leukemia. Leukemia. 2007; 21(9):1901-1906.

65. Radich JP, Dai H, Mao M, Oehler V, Schelter J, Druker B, Sawyers C, Shah N, Stock W, Willman CL, Friend S and Linsley PS. Gene expression changes associated with progression and response in chronic myeloid leukemia. PNAS. 2006; 103(8):2794-2799.

66. WHO. World Health Organization Classification of Tumors of Haematopoietic and Lymphoid Tissues, 4th Edition. (Lyon: international Agency for Cancer). 2008.

67. Steelman LS, Abrams SL, Whelan J, Bertrand FE, Ludwig DE, Basecke J, Libra M, Stivala F, Milella M, Tafuri A, Lunghi P, Bonati A, Martelli AM and McCubrey JA. Contributions of the Raf/MEK/ERK, PI3K/PTEN/Akt/ mTOR and Jak/STAT pathways to leukemia. Leukemia. 2008; 22(4):686-707.

68. Hers I, Vincent EE and Tavare JM. Akt signalling in health and disease. Cell Signal. 2011; 23(10):1515-1527.

69. Benekli M, Xia Z, Donohue KA, Ford LA, Pixley LA, Baer MR, Baumann $\mathrm{H}$ and Wetzler M. Constitutive activity of signal transducer and activator of transcription 3 protein in acute myeloid leukemia blasts is associated with short disease-free survival. Blood. 2002; 99(1):252-257.

70. Reikvam H, Tamburini J, Skrede S, Holdhus R, Poulain L, Ersvaer E, Hatfield KJ and Bruserud O. Antileukaemic 
effect of PI3K-mTOR inhibitors in acute myeloid leukaemia-gene expression profiles reveal CDC25B expression as determinate of pharmacological effect. Br J Haematol. 2014; 164(2):200-211.

71. Hutchins AP, Diez D and Miranda-Saavedra D. Genomic and computational approaches to dissect the mechanisms of STAT3's universal and cell type-specific functions. JakStat. 2013; 2(4):e25097.

72. Bruserud O, Nepstad I, Hauge M, Hatfield K and Reikvam H. STAT3 as a possible therapeutic target in human malignancies: Lessions from acute myeloid leukemia. Exp Rev Hematol. 2014; 6:1-13.

73. Marvin J, Swaminathan S, Kraker G, Chadburn A, Jacobberger J and Goolsby C. Normal bone marrow signaltransduction profiles: a requisite for enhanced detection of signaling dysregulations in AML. Blood. 2011; 117(15):e120-130.

74. Redell MS, Ruiz MJ, Alonzo TA, Gerbing RB and Tweardy DJ. Stat3 signaling in acute myeloid leukemia: liganddependent and -independent activation and induction of apoptosis by a novel small-molecule Stat 3 inhibitor. Blood. 2011; 117(21):5701-5709.

75. Mandal T, Bhowmik A, Chatterjee A, Chatterjee U, Chatterjee S and Ghosh MK. Reduced phosphorylation of Stat 3 at Ser-727 mediated by casein kinase 2 - Protein phosphatase 2A enhances Stat3 Tyr-705 induced tumorigenic potential of glioma cells. Cell Signal. 2014; 26(8):1725-1734.

76. Huang G, Yan H, Ye S, Tong C and Ying QL. STAT3 phosphorylation at tyrosine 705 and serine 727 differentially regulates mouse ESC fates. Stem Cells. 2014; 32(5):11491160 .

77. Miyakoshi M, Yamamoto M, Tanaka H and Ogawa K. Serine 727 phosphorylation of STAT3: an early change in mouse hepatocarcinogenesis induced by neonatal treatment with diethylnitrosamine. Molec Carcinogen. 2014; 53(1):67-76.

78. Wakahara R, Kunimoto H, Tanino K, Kojima H, Inoue A, Shintaku H and Nakajima K. Phospho-Ser727 of STAT3 regulates STAT3 activity by enhancing dephosphorylation of phospho-Tyr705 largely through TC45. Genes Cells. 2012; 17(2):132-145.

79. Nosaka T, Kawashima T, Misawa K, Ikuta K, Mui AL and Kitamura T. STAT5 as a molecular regulator of proliferation, differentiation and apoptosis in hematopoietic cells. EMBO J. 1999; 18(17):4754-4765.

80. McCubrey JA, Steelman LS, Chappell WH, Abrams SL, Franklin RA, Montalto G, Cervello M, Libra M, Candido S, Malaponte G, Mazzarino MC, Fagone P, Nicoletti F, Basecke J, Mijatovic S, Maksimovic-Ivanic D, et al. Ras/ Raf/MEK/ERK and PI3K/PTEN/Akt/mTOR cascade inhibitors: how mutations can result in therapy resistance and how to overcome resistance. Oncotarget. 2012; 3(10):1068-1111. 